DOI : https://doi.org/10.24123/jbt.v5i1.4085

\title{
GOOD CORPORATE GOVERNANCE DAN PERLINDUNGAN KONSUMEN: STUDI KASUS: PENYALAHGUNAAN DATA KARTU TELEPON BEKAS
}

\author{
Angeline Thalita \\ Fakultas Hukum Universitas Surabaya;Raya Kalirungkut, Surabaya 60293 \\ Email : thalitaangeline@gmail.com
}

\begin{abstract}
This study aimed to investigate the extent of the application of the principles of Good Corporate Governance (GCG) and protection of personal data from the point of view of consumers in telecommunications service companies. The case study analyzed the misuse of used telephone card data in a telecommunications service company PT. Z. The empirical judicial method was used in this study. This legal research was carried out by examining documents (document studies), using 2 (two) approaches, the statute approach and the conceptual approach. Primary data were collected through surveys and interviews to prove the findings in the first stage. The results of the study, on the legal aspects showed that the legal protection for consumers as users of telecommunications services has not been fully implemented by PT. Z according to Law Number 8 of 1999 concerning Consumer Protection and Law Number 36 of 1999 concerning Telecommunications. Consumer perceptions indicate that PT. Z has not implemented GCG principles properly. Consumer responses to aspects of consumer personal data protection related to the above cases are also not good and tend to be detrimental to consumers. This research showed that the application of GCG principles is not optimal and has an impact on weak aspects of consumer protection. For the implementation of GCG in the future, PT. Z should have good intentions in running its business and provide correct, complete and clear information related to the products it trades, both spoken and written.
\end{abstract}

Keywords : Good corporate governance, consumer protection, personal data protection, telecommunication service

\section{Pendahuluan}

Perkembangan teknologi telah mentransformasi industri telekomunikasi di dunia. Pergeseran telekomunikasi legacy (voice dan SMS) menjadi telekomunikasi berbasiskan data didukung oleh perkembangan internet yang begitu massif. Ketersediaan infrastruktur dan akses telekomunikasi, di Indonesia telah mendorong pertumbuhan penggunaan internet melalui akses wireless meningkat pesat. Pertumbuhan trafik penggunaan data di Indonesia meningkat setiap tahunnya. Fakta menunjukkan bahwa sektor jasa telekomunikasi telah memberikan kontribusi terhadap PDB Indonesia sebagai penyumbang terbesar bagi pendapatan negara bukan pajak (PNBP) dari sektor Informasi dan Komunikasi, melalui pembayaran Biaya Hak Penggunaan Frekuensi (BHP). Akan tetapi, jika dilihat dari tren, share jasa telekomunikasi terhadap PDB 
Informasidan Komunikasi mengalami penurunan (Kemkominfo, 2018:1). Berbagai upaya perlu dilakukan mempelajari berbagai kemungkinan penyebab penurunan tersebut.

Disisi lain, perkembangan teknologi khususnya teknologi informasi dan komunikasi, telah banyak memberikan keuntungan bagi penduduk dunia untuk saling terhubung antara yang satu dengan yang lainnya. Selain digunakan untuk berkomunikasi, perkembangan teknologi tersebut juga mendorong penciptaan produk atau layanan baru dimana telepon seluler dapat digunakan untuk layanan multimedia seperti video on demand, teleshopping, permainan interaktif, sistem komunikasi dan informasi interaktif berkecepatan tinggi serta terhubung pada email, fitur perbankan dan sebagainya (Budhijanto, 2014:135).

Semakin banyaknya produk dan layanan tersebut dikarenakan semakin banyak operator telepon seluler yang menawarkan produk berupa barang atau jasa di bidang telekomunikasi. Masing-masing operator berlomba untuk menawarkan produknya kepada konsumen bahkan memberikan janji yang bermacam-macam, mulai tarif murah hingga bonus atau hadiah yang didapatkan bilamana pelanggan penggunaanya telah mencapai batas tertentu. Semakin banyak operator telepon seluler yang ada membuat persaingan diantara operator yang satu dengan yang lain semakin ketat. Di satu sisi hal tersebut berdampak baik yaitu terciptanya kompetisi untuk mencapai derajat yang lebih tinggi serta menjadi yang terbaik, namun di sisi lain hal tersebut memicu munculnya persaingan yang tidak sehat antara satu pelaku usaha dengan pelaku usaha lainnya.

Salah satu masalah yang kerap kali merugikan konsumen khususnya sebagai pelanggan jasa telekomunikasi yaitu dalam hal perlindungan kerahasiaan dan keamanan data pribadi. Menurut Latumahina (2014:16), Suatu data dapat dikatakan sebagai data pribadi apabila data tersebut berhubungan dengan seseorang serta dapat digunakan untuk mengidentifikasi orang tersebut sebagai pemilik data.

Selain kajian aspek hukum tentang siapa yang seharusnya bertanggung gugat atas kerugian yang diderita oleh konsumen, upaya pembenahan Good Corporate Governance (GCG) atau tata kelola perusahaan yang baik dapat menjadi jawaban agar kasus terkait perlindungan konsumen dapat dihindari dimasa depan. Mudashiru, Bakare, dan Ishmael (2014:174) mengatakan penerapan GCG yang optimal, selain memberikan dampak pada kinerja perusahaan, akan memberikan perlindungan kepada semua pemangku kepentingan, termasuk konsumen selaku pemangku kepentingan eksternal. Sebaliknya, jika penerapan prinsip GCG tidak berjalan secara optimal akan memunculkan ketidakpercayaan konsumen karena merasa perlindungan terhadap mereka sangat lemah (Taolin, Utomo, Wahyudi dan Pangestuti, 2019:39). Studi penerapan prinsip GCG sebelumnya lebih cenderung mengatur hubungan antara berbagai pihak yang berkepentingan terutama dalam arti sempit, seperti hubungan antara pemegang saham, dewan komisaris, dan dewan direksi demi tercapainya tujuan perusahaan. Selain itu, Penilaian penerapan prinsip-prinsip GCG di Indonesia masih terbatas dan memiliki berbagai kekurangan (Wawondos dan Mustamu, 2014:1). Studi terhadap penerepan prinsip-prinsip GCG yang dikaitkan dengan aspek perlindungan konsumen, khususnya di tinjau dari sudut pandang konsumen relatif masih terbatas.

Penelitian ini bertujuan untuk mengetahui sejauh mana keterkaitan penerapan prinsip-prinsip Good Corporate Governance (GCG) dan perlindungan data pribadi dari sudut pandang aspek hukum dan tanggapan konsumen pada perusahaan jasa telekomunikasi. 


\section{Landasan Teori}

\section{Good Corporate Governance (GCG)}

GCG secara definitif merupakan sistem yang mengatur dan mengendalikan perusahaan untuk menciptakan nilai tambah (value added) untuk semua pemangku kepentingan, baik internal maupun eksternal. Konsep GCG di Indonesia dapat diartikan sebagai konsep tata kelola perusahaan yang baik. Menurut Organization of Economic Cooperation and Development (OECD), GCG merupakan sekumpulan hubungan antara pihak manajemen perusahaan, board, pemegang saham, dan pihak lain yang mempunyai kepentingan dengan perusahaan (OECD, 2004:11). Corporate governance mensyaratkan adanya struktur perangkat untuk mencapai tujuan dan pengawasan atas kinerja. Corporate governance yang baik dapat memberikan pengaruh bagi board dan manajemen untuk mencapai tujuan yang merupakan kepentingan perusahaan dan pemegang saham harus memfasilitasi pengawasan yang efektif sehingga mendorong perusahaan menggunakan sumber daya yang lebih efisien. (Dalam Surya \& Yustiavandana, 2006:25). Selain itu, GCG dapat didefinisikan sebagai tata kelola perusahaan yang memberikan jaminan berlansungnya sistem dan proses pengambilan keputusan organ perusahaan berlandaskan pada prinsip keadilan, transparan, bertanggung jawab, dan akuntabel. Dalam proses pengambilan keputusan, organ perusahaan ini juga sangat terkait dengan pemangku kepentingan perusahaan, seperti konsumen, masyarakat, pemerintah, pemasok, media dan lembaga swadaya masyarakat. GCG memiliki prinsip dasar yang disebut TARIF yaitu Transparansi, Akuntabilitas, Responsibilitas, Independensi, dan Fairness yang dapat diterapkan pada perusahaan sebagai pedoman (Wawondos dan Mustamu, 2014:2). Penerapan prinsip - prinsip Good Corporate Governance membantu setiap perusahaan untuk menciptakan nilai tambah bagi semua pihak yang berkepentingan. Hal tersebut dapat dipastikan bahwa prinsip - prinsip GCG diterapkan pada setiap aspek bisnis dan disemua jajaran perusahaan.

\section{Pelindungan Konsumen}

Di Indonesia mengenai perlindungan konsumen diatur oleh Undang-Undang Nomor 8 Tahun 1999 Tentang Perlindungan Konsumen (UUPK). UUPK menyatakan bahwa, perlindungan konsumen adalah segala upaya yang menjamin adanya kepastian hukum untuk memberi perlindungan kepada konsumen. Cakupan perlindungan konsumen itu dapat dibedakan dalam dua aspek, yaitu (Rajagukguk,2000:10): (1) perlindungan terhadap kemungkinan barang yang diserahkan kepada konsumen tidak sesuai dengan apa yang telah disepakati, dan (2) perlindungan terhadap diberlakukannya syarat-syarat yang tidak adil kepada konsumen. Hukum perlindungan konsumen adalah bagian dari hukum konsumen yang memuat asas-asas atau kaidah-kaidah yang bersifat mengatur dan mengandung sifat yang melindungi kepentingan konsumen, sedangkan hukum konsumen adalah hukum yang mengatur hubungan dan masalah antara berbagai pihak satu sama lain berkaitan dengan barang atau jasa.

Hukum perlindungan konsumen merupakan upaya hukum untuk melindungi konsumen (warga negara) dari perbuatan curang oknum pelaku usaha baik dari dalam negeri maupun dari luar negeri. Oleh karena itu, hukum perlindungan konsumen merupakan upaya kongkrit yang dilakukan oleh negara dan pemerintah untuk melindungi konsumen (warga negara) sebagaimana amanah dari konsepsi negara hukum kesejahteraan yang termuat dalam amanah konstitusi UUD 1945 Semestinya korporasi harus mewujudkan perlindungan konsumen sebagai strategi untuk menarik simpati konsumen termasuk agar produk yang di hasilkan dapat diterima oleh konsumen (Mansyur dan Rahman, 2015:3).

Dalam Pasal 1 UUPK, mengindikasikan bahwa perlindungan konsumen merupakan segala bentuk upaya pemerintah untuk menjamin kepastian hukum untuk melindungi konsumen. Tujuan dari UUPK adalah untuk melindungi kepentingan konsumen ketika 
bertransaksi yang sekaligus dapat menjadi acuan pelaku usaha untuk dapat meningkatkan mutu produk yang dijualnya. Dalam pasal 7 UUPK, mengatur mengenai berbagai kewajiban yang harus di penuhi pelaku usaha, ketika menawarkan dan menjual suatu produk, yakni (Nugrahaningsih dan Erlinawati,2017:29):

- Memiliki itikad baik saat menjalankan usahanya.

- Memberikan informasi yang sebenarnya, jelas, serta jujur mengenai kondisi dan jaminan barang/jasa serta memberikan kejelasan penggunaan, perbaikan dan pemeliharaan atas produk yang di jualnya.

- Tidak diskriminatif, sehingga dapat memperlakukan atau melayani konsumen secara benar dan jujur.

- Memberikan jaminan berupa mutu barang dan jasa yang diproduksinya berdasarkan ketentuan standar mutu barang dan jasa yang berlaku.

- Memperbolehkan konsumen untuk menguji, dan/atau mencoba barang serta memberikan garansi atas barang yang dibuat atau diperdagangkan.

- Memberikan kompensasi berupa ganti rugi atau penggantian atas kerugian akibat penggunaan, pemakaian, dan pemanfaatan barang dan atau jasa yang diperdagangkan.

- Memberikan kompensasi atau ganti rugi berupa penggantian barang apabila barang atau jasa yang diterima atau dimanfaatkan tidak sesuai dengan yang ditawarkan.

\section{GCG dan perlindungan konsumen}

Beberapa penelitian sebelumnya telah menunjukan bahwa penerapan prinsip GCG secara optimal akan memberi pengaruh positif terhadap kinerja perusahaan secara keseluruhan (Peni dan Vähämaa, 2011; Zhang, Lu, and Li, 2011; Shank, Hill dan Stang, 2013). Mudashiru, Bakare, dan Ishmael (2014:174) mengatakan penerapan GCG yang optimal, selain memberikan dampak pada kinerja perusahaan, akan memberikan perlindungan kepada semua pemangku kepentingan, termasuk konsumen selaku pemangku kepentingan eksternal. Sebaliknya, jika penerapan prinsip GCG tidak berjalan secara optimal akan memunculkan ketidakpercayaan konsumen karena merasa perlindungan terhadap mereka sangat lemah (Taolin, Utomo, Wahyudi dan Pangestuti, 2019:39). Disisi lain, beberapa penelitian menunjukan upaya perlindungn konsumen yang baik memberi pengaruh pada kepuasan konsumen. Selvakumar dan Sathyalakshmi (2015:71) mengatakan bahwa perlindungan konsumen yang baik memberi dampak signifikan terhadap kepuasan konsumen pada bidang jasa keuangan. Sondakh, Worang dan Pandowo (2017:3534) menyatakan bahwa ada hubungan antara perlindungan konsumen dengan kepuasaan konsumen apa jasa asuransi. Tjizumaue (2019:184) mengatakan bahwa perlindungan konsumen yang baik akan memberi pengaruh positif terhadap kepuasan dan loyalitas konsumen. Hasil penelitian diatas menunjukan bahwa suatu perusahaan yang dapat menjalan prinsip GCG secara optimal harusnya akan memberi kondisi perlindungan konsumen yang baik dan selanjutnya memberikan kepuasan bagi konsumen serta perbaikan kinerja bagi perusahaan secara keseluruhan.

\section{Metodologi Penelitian}

Metode yang digunakan dalam penelitian ini adalah metode empiris yudiris yaitu penelitian hukum yang dilakukan dengan cara meneliti bahan pustaka, dengan menggunakan 2 (dua) pendekatan masalah statute approach dan conceptual approach, dan pengumpulan data primer melalui survey dan wawancara. Penelitian bahan pustaka atau data sekunder dilakukan dengan cara mengadakan penelusuran terhadap peraturanperaturan dan literatur-literatur yang berkaitan dengan permasalahan yang diteliti. Statute approach dilakukan dengan menelaah semua undang-undang dan regulasi yang bersangkut paut dengan isu hukum yang sedang ditangani. Sedangkan conceptual 
approach dilakukan dengan mengkaji pandangan-pandangan dan doktrin-doktrin yang berkembang di dalam ilmu hukum (Marzuki, 2011:93). Bahan hukum yang digunakan dalam penelitian ini yaitu bahan hukum primer dan bahan hukum sekunder. Bahan hukum primer yaitu bahan hukum yang bersifat mengikat, berupa peraturan perundangundangan, antara lain UUPK dan Undang-Undang Nomor 36 Tahun 1999 Tentang Telekomunikasi (UU Telekomunikasi). Sedangkan bahan hukum sekunder, yaitu bahan hukum yang bersifat menjelaskan bahan hukum primer, yang berupa buku-buku literatur, karya ilmiah dan berbagai media cetak yang ada kaitannya dengan permasalahan yang dibahas.

Pengumpulan data primer dilakukan melalui survey dan wawancara. Tujuan pengumpulan data primer adalah untuk meminta tanggapan konsumen terhadap penerapan 5 (lima) prinsip GCG dan aspek perlindungan konsumen. Sampel responden survey adalah konsumen pengguna jasa telekomunikasi PT. Z yang pernah mengalami permasalahan dengan perlindungan data pribadi. Survey menggunakan google form Penggunaan google form dalam survey online di masa pandemic Covid 19 telah digunakan oleh beberapa peneliti (Sianipar, 2019:16; Lianto et al.,2020:11). Aplikasi ini sangat cocok digunakan untuk mengumpulkan pendanpat sekelompok orang yang berjauhan dan sulit untuk dikumpulkan (Batubara, 2016:41). Survey dilakukan kepada 100 pengguna jasa telekomunikasi PT. Z. Jumlah responden yang sesuai dengan bersedia menjawab pertanyaan survey secara lengkap berjumlah 72 responden. Proses wawancara dilakukan peneliti terhadap beberapa petugas penjaga counter resmi jasa telekomunikasi PT. Z untuk melihat prosedur dan tahapan penggunaan data kartu telepon bekas.

Parameter GCG yang digunakan dalam survey adalah menggunakan konsep TARIF, sebagai berikut (Wawandos dan Mustamu, 2014)

- Keterbukaan (Transparancy): Operator seluler yang anda gunakan menjelaskan secara terbuka dan jelas dampak dan konsekuensi serta hak dan kewajiban pengguna jasa telekomunikasi.

- Akuntabilitas (Accountability): Operator seluler yang anda gunakan menjalankan kewajiban memberikan informasi yang benar, jelas dan jujur terkait produk dan/atau layanan yang diberikan.

- Pertanggungjawaban (Responsibility): Operator seluler yang anda gunakan bertanggung jawab jika terjadi permasalahan terhadap penyalahgunaan data pribadi pengguna jasa telekomunikasi.

- Independensi (Independency): Operator seluler yang anda gunakan memberikan layanan yang profesional dan bebas dari benturan kepentingan.

- Kewajaran (Fairness): Operator seluler yang anda gunakan memberikan perlakuan yang adil terkait hak dan kewajiban pengguna jasa telekomunikasi.

Sedangkan aspek perlindungan konsumen, menggunakan pernyataan sebagai berikut (Nugrahaningsih dan Erlinawati,2017:29):

- Perlindungan Konsumen: Sebagai pengguna produk dan layanan operator seluler, anda merasa perlindungan konsumen telah terjaga dengan baik.

- Operator seluler yang anda gunakan memberikan informasi yang jelas dan jujur bilamana terjadi daur ulang terhadap SIM Card yang pernah anda gunakan.

Skala tanggapan konsemen menggunakan skala likert 1-5, dengan keterangan sebagai berikut: $1=$ sangat tidak setuju; $2=$ tidak setuju; $3=$ netral; $4=$ setuju; $5=$ sangat setuju. Pengolahan dan analisis data menggunakan metode statistik deskriptif. 


\section{Hasil dan Pembahasan Studi Kasus}

Sebuah kasus dialami oleh seorang konsumen sekaligus pelanggan jasa telekomunikasi dan penyelenggara jasa telekomunikasi. Kasus tersebut terjadi pada tanggal 22 Juli 2018, diawali dengan X menonaktifkan nomor telepon seluler PT. Z miliknya di Kantor pelayanan PT. Z pada sebuah mall di Surabaya dengan alasan tertentu. Nomor telepon seluler tersebut selama ini terhubung dengan semua kartu kredit dan email miliknya. Pada saat menonaktifkan, $\mathrm{X}$ yakin semua data yang terhubung dengan nomor tersebut akan terhapus termasuk nomor-nomor kartu kreditnya namun ternyata PT. Z mendaur ulang, mengaktifkan dan menjual kembali nomor telepon seluler lama milik $\mathrm{X}$ tersebut tanpa ada pemberitahuan sebelumnya.

Pada tanggal 28 April 2019 X sebagai pemilik nomor lama mulai curiga karena tidak dapat mengakses email miliknya, padahal $\mathrm{X}$ telah memasukan alamat email dan password yang benar. $\mathrm{X}$ kemudian menggunakan opsi lupa password agar dapat membuat password baru untuk akun email miliknya. Langkah selanjutnya untuk membuat password baru yaitu melakukan verifikari email berupa pengiriman SMS (short message service) pada nomor telepon yang terhubung pada email tersebut namun email milik $\mathrm{X}$ terhubung dengan nomor telepon seluler miliknya yang telah dinonaktifkan sehingga kode verifikasi email tersebut dikirim oleh sistem ke nomor telepon seluler $\mathrm{X}$ yang lama. $\mathrm{X}$ tidak dapat melihat kode verifikasi tersebut dikarenakan nomor telepon seluler lamanya telah menjadi milik orang lain, karena kejadian tersebut email X diretas oleh orang yang menggunakan nomor telepon seluler lamanya dan $\mathrm{X}$ mendapati serentetan penggunaan pada kartu kredit miliknya di enam bank.

Penggunaan kartu kredit oleh pihak lain dengan cara meretas tersebut terjadi pada bank A dengan 4 transaksi pembelanjaan di salah satu toko online senilai Rp 25.300.000. Selain itu X juga ditagih bank B senilai Rp 28.000.000. Pada bank C, X ditagih senilai $\mathrm{Rp} 1.700 .000$ untuk 7 transaksi kartu kredit oleh pihak lain berupa pembelian pulsa di aplikasi belanja online. Tindakan tersebut terus berlangsung hingga pada tanggal 22 Mei 2019, yaitu bank D ada transaksi kartu kredit oleh pihak lain sebesar Rp 9.300.000. Begitu pula pada bank E 3 kali transaksi dan pada bank F 12 kali transaksi, kesemuanya itu tidak dikenali oleh Bufi sejumlah Rp 23.700.000. Total kerugian yang dialami oleh $\mathrm{X}$ akibat kegiatan pihak lain meretas kartu kredit miliknya pada bank-bank tersebut diatas adalah senilai Rp 88.000.000.

\section{Kajian aspek hukum}

Pada kasus yang dialami oleh $\mathrm{X}$ tersebut terdapat hak-hak $\mathrm{X}$ sebagai konsumen yang dilanggar oleh PT. Z sebagai pelaku usaha sebagai berikut:

a. hak atas kenyamanan, keamanan, dan keselamatan dalam mengkonsumsi barang dan/atau jasa sebagaimana diatur dalam Pasal 4 huruf a UUPK. X sebagai konsumen mengalami kerugian karena menggunakan kartu pascabayar milik PT. Z yang mana telah dinonaktifkan oleh X pada tanggal 28 Juli 2018. Nomor tersebut ternyata didaur ulang oleh PT. Z, diperjualbelikan kembali, dan dibeli serta digunakan oleh pihak lain. Hal ini tentu membuat $X$ merasa tidak aman dan nyaman, karena pada saat menonaktifkan nomor telepon selulernya $\mathrm{X}$ tidak mendapatkan informasi baik secara lisan maupun tertulis mengenai daur ulang kartu SIM tersebut. Apabila kartu SIM milik X didaur ulang dan diaktifkan kembali maka tidak menutup kemungkinan untuk disalahgunakan oleh pemegang nomor yang baru.

b. hak atas informasi yang benar, jelas, dan jujur mengenai kondisi dan jaminan barang dan/atau jasa sebagaimana diatur dalam Pasal 4 huruf c UUPK. Terkait dengan 
ketentuan pasal ini pihak PT. Z melanggar hak konsumen karena tidak memberikan informasi yang benar, jelas dan jujur kepada $X$ bersangkutan dengan semua informasi mengenai produk kartu pascabayar miliknya. PT. Z sebagai pelaku usaha tentu yang paling tahu mengenai seluruh kondisi dan informasi produk yang diperdagangkannya, namun tidak memberikan informasi baik lisan maupun tertulis bahwa nomor telepon seluler yang dinonaktifkan dapat didaur ulang dan dirilis kembali. Sehubungan dengan hal tersebut maka dapat dikatakan pihak PT. Z sekaligus melanggar kewajiban pelaku usaha Pasal 7 huruf b UUPK menentukan sebagai berikut : "memberikan informasi yang benar, jelas dan jujur mengenai kondisi dan jaminan barang dan/atau jasa serta memberi penjelasan penggunaan, perbaikan dan pemeliharaan;".

Pihak PT. Z di sisi lain juga tidak menjalankan kewajibannya sebagaimana tercantum dalam pasal 7 huruf a UUPK yaitu: "beritikad baik dalam melakukan kegiatan usahanya;". Menurut Khairandy (2003:128), Itikad baik merupakan asas yang sangat penting dalam hukum kontrak. Itikad baik memiliki dua dimensi, yakni dimensi pertama adalah dimensi subjektif, yang berarti itikad baik mengarah kepada makna kejujuran. Dimensi yang kedua adalah dimensi objektif, yang memaknai itikad baik sebagai kerasionalan dan kepatutan dan keadilan. Terkait dengan perbuatan yang dilakukan PT. Z maka dapat dikatakan pihak PT. Z tidak melakukan itikad baik dalam dimensi subjektif yaitu tidak adanya kejujuran dalam menjalankan usahanya.

Pasal 21 UU Telekomunikasi menentukan sebagai berikut: "Penyelenggara telekomunikasi dilarang melakukan kegiatan usaha penyelenggaraan telekomunikasi yang bertentangan dengan kepentingan umum, kesusilaan, keamanan, atau ketertiban umum." Kegiatan daur ulang nomor telepon yang telah dinonaktifkan tanpa memberikan informasi lisan maupun tertulis kepada pelanggan yang dilakukan oleh pihak PT. Z tersebut bertentangan dengan keamanan pelanggan. Kegiatan tersebut membuka peluang terjadinya penyalahgunaan nomor telepon seluler dan tidak menjamin keamanan $\mathrm{X}$ sebagai pelanggan jasa telekomunikasi PT. Z.

Nomor telepon seluler yang dimiliki oleh $\mathrm{X}$ merupakan data pribadi yang harus dilindungi mengingat terlekat pula data-data dan identitas X pada nomor tersebut. Pada Pasal 26 huruf a Peraturan Menteri Komunikasi dan Informatika nomor 20 Tahun 2016 Tentang Perlindungan Data Pribadi Dalam Sistem Elektronik (Peraturan Menteri Komunikasi 20 Tahun 2016) ditentukan hak pemilik data pribadi yaitu hak atas kerahasiaan data pribadinya, dimana hak tersebut bertimbal balik dengan kewajiban pengguna data pribadi pada Pasal 27 huruf a dan c Peraturan Menteri Komunikasi 20 Tahun 2016 yaitu menjaga kerahasiaan dan melindungi Data Pribadi yang diperoleh, dikumpulkan, diolah dan dianalisisnya dari tindakan penyalahgunaan.

\section{Kajian dan analisis implementasi prinsip GCG dan perlindungan konsumen}

Berdasarkan hasil survey kepada pengguna terkait tanggapan konsumen terhadap implementasi prinsip GCG (menggunakan komponen TARIF) ada PT. Z, diperoleh data sebagai berikut:

Tabel. 1 Tanggapan konsumen terhadap aspek perlindungan konsumen

\begin{tabular}{|c|c|c|c|c|c|c|c|c|c|c|c|c|}
\hline No & T & A & R & I & F & & No & T & A & R & I & F \\
\hline 1 & 2 & 1 & 2 & 3 & 2 & 37 & 2 & 4 & 1 & 2 & 2 \\
\hline 2 & 2 & 1 & 1 & 2 & 3 & 38 & 1 & 2 & 1 & 4 & 2 \\
\hline
\end{tabular}




\begin{tabular}{|c|c|c|c|c|c|c|c|c|c|c|c|c|}
\hline 3 & 1 & 2 & 1 & 4 & 1 & 39 & 2 & 1 & 3 & 2 & 3 \\
\hline 4 & 2 & 2 & 2 & 2 & 2 & 40 & 3 & 3 & 2 & 3 & 2 \\
\hline 5 & 5 & 5 & 5 & 5 & 5 & 41 & 2 & 2 & 1 & 4 & 4 \\
\hline 6 & 5 & 5 & 5 & 1 & 5 & 42 & 2 & 3 & 1 & 4 & 2 \\
\hline 7 & 2 & 3 & 2 & 4 & 3 & 43 & 2 & 2 & 2 & 2 & 3 \\
\hline 8 & 3 & 2 & 4 & 3 & 2 & 44 & 2 & 2 & 1 & 4 & 4 \\
\hline 9 & 4 & 2 & 2 & 4 & 4 & 45 & 2 & 2 & 2 & 3 & 3 \\
\hline 10 & 4 & 2 & 2 & 5 & 4 & 46 & 2 & 2 & 2 & 2 & 3 \\
\hline 11 & 4 & 4 & 2 & 4 & 2 & 47 & 3 & 2 & 2 & 3 & 2 \\
\hline 12 & 4 & 2 & 1 & 4 & 2 & 48 & 1 & 2 & 2 & 2 & 3 \\
\hline 13 & 4 & 4 & 2 & 5 & 4 & 49 & 2 & 2 & 1 & 4 & 2 \\
\hline 14 & 4 & 4 & 2 & 4 & 4 & 50 & 2 & 2 & 3 & 2 & 2 \\
\hline 15 & 4 & 4 & 4 & 4 & 4 & 51 & 2 & 4 & 1 & 4 & 2 \\
\hline 16 & 4 & 4 & 2 & 4 & 5 & 52 & 3 & 3 & 3 & 2 & 1 \\
\hline 17 & 4 & 2 & 4 & 4 & 4 & 53 & 2 & 3 & 1 & 1 & 2 \\
\hline 18 & 4 & 3 & 2 & 5 & 3 & 54 & 2 & 2 & 3 & 2 & 1 \\
\hline 19 & 4 & 4 & 2 & 2 & 3 & 55 & 2 & 4 & 1 & 2 & 1 \\
\hline 20 & 2 & 4 & 2 & 4 & 5 & 56 & 3 & 3 & 3 & 2 & 2 \\
\hline 21 & 2 & 2 & 2 & 4 & 5 & 57 & 3 & 2 & 1 & 1 & 2 \\
\hline 22 & 3 & 2 & 4 & 4 & 5 & 58 & 4 & 4 & 2 & 4 & 4 \\
\hline 23 & 4 & 4 & 2 & 5 & 4 & 59 & 2 & 2 & 3 & 2 & 2 \\
\hline 24 & 2 & 4 & 2 & 3 & 3 & 60 & 2 & 2 & 1 & 2 & 2 \\
\hline 25 & 4 & 2 & 3 & 4 & 5 & 61 & 2 & 3 & 2 & 3 & 2 \\
\hline 26 & 4 & 2 & 2 & 4 & 4 & 62 & 1 & 2 & 2 & 1 & 2 \\
\hline 27 & 2 & 4 & 1 & 5 & 3 & 63 & 3 & 2 & 3 & 2 & 3 \\
\hline 28 & 4 & 2 & 4 & 4 & 3 & 64 & 2 & 2 & 1 & 3 & 3 \\
\hline 29 & 4 & 4 & 4 & 3 & 4 & 65 & 3 & 3 & 2 & 2 & 3 \\
\hline 30 & 2 & 4 & 2 & 4 & 4 & 66 & 2 & 2 & 1 & 3 & 3 \\
\hline 31 & 2 & 4 & 2 & 4 & 4 & 67 & 3 & 3 & 2 & 3 & 2 \\
\hline 32 & 2 & 4 & 1 & 4 & 4 & 68 & 2 & 2 & 1 & 2 & 2 \\
\hline 33 & 3 & 3 & 2 & 4 & 4 & 69 & 2 & 2 & 3 & 2 & 2 \\
\hline 34 & 2 & 4 & 2 & 4 & 4 & 70 & 3 & 3 & 2 & 3 & 2 \\
\hline 35 & 2 & 4 & 1 & 4 & 4 & 71 & 1 & 1 & 1 & 1 & 1 \\
\hline 36 & 2 & 2 & 1 & 2 & 2 & 72 & 1 & 1 & 1 & 1 & 1 \\
\hline
\end{tabular}

Rerata tanggapan konsumen pada masing-masing komponen TARIF adalah sebagai berikut:

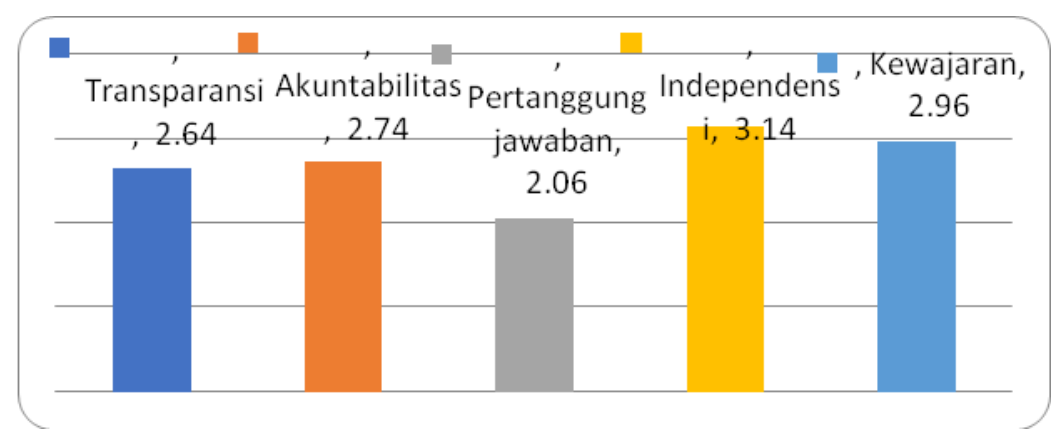

Gambar 1. Rerata tangapan konsumen terhadap komponen TARIF 
Dari gambar di atas terlihat bahwa secara keseluruhan proses implementasi prinsipprinsip GCG di PT. Z dari sudut pandang konsumen belum optimal dengan nilai mean 2,70. Sebagain besar konsumen berpendapat antara tidak setuju dan netral ketika dinyatakan bahwa implementasi prinsip GCG di PT. Z terlah berjalan optimal. Komponen TARIF yang memiliki nilai mean terendah adalah Responsibility (2.06). Sebagian besar konsumen menyatakan bahwa PT. Z tidak bertanggung jawab jika terjadi permasalahan terhadap penyalahgunaan data pribadi pengguna jasa telekomunikasi. Nilai mean tertinggi berada pada komponen Independent (3.14). hal ini menunjukan bahwa konsumen PT. Z ragu-ragu (netral) untuk member penilaian bahwa perusahaan telah memberikan layanan yang profesional dan bebas dari benturan kepentingan.

Dari aspek perlindungan konsumen, data tanggapan konsumen dapat dilihat pada tabel berikut:

Tabel. 2 Tanggapan konsumen terhadap aspek perlindungan konsumen

\begin{tabular}{|c|c|c|c|c|c|c|c|c|c|c|c|c|c|c|c|c|}
\hline \multirow{5}{*}{$\begin{array}{l}\text { Sebagai } \\
\text { pengguna } \\
\text { produk dan } \\
\text { layanan } \\
\text { operator } \\
\text { seluler, anda } \\
\text { merasa } \\
\text { perlindungan } \\
\text { konsumen } \\
\text { telah terjaga } \\
\text { dengan baik }\end{array}$} & 1 & 2 & 2 & 4 & 5 & 5 & 2 & 2 & 4 & 2 & 2 & 2 & 4 & 5 & 4 & \multirow{5}{*}{$\begin{array}{c}\text { Rerata : } 2,43 \\
(\mathrm{n}=72)\end{array}$} \\
\hline & 5 & 2 & 4 & 2 & 2 & 4 & 4 & 4 & 4 & 5 & 2 & 3 & 2 & 5 & 2 & \\
\hline & 2 & 3 & 4 & 2 & 4 & 1 & 1 & 2 & 2 & 1 & 3 & 1 & 2 & 1 & 1 & \\
\hline & 1 & 1 & 1 & 3 & 1 & 3 & 2 & 2 & 2 & 2 & 1 & 2 & 4 & 1 & 3 & \\
\hline & 1 & 2 & 1 & 2 & 1 & 4 & 1 & 2 & 2 & 2 & 1 & 1 & & & & \\
\hline \multirow{5}{*}{$\begin{array}{l}\text { Operator } \\
\text { memberikan } \\
\text { informasi } \\
\text { yang jelas dan } \\
\text { jujur bilamana } \\
\text { terjadi daur } \\
\text { ulang terhadap } \\
\text { SIM Card } \\
\text { yang pernah } \\
\text { anda gunakan }\end{array}$} & 1 & 1 & 1 & 2 & 5 & 1 & 1 & 1 & 2 & 1 & 1 & 2 & 1 & 3 & 4 & \multirow{5}{*}{$\begin{array}{c}\text { Rerata : } 1,74 \\
\quad(n=72)\end{array}$} \\
\hline & 2 & 2 & 4 & 1 & 1 & 3 & 4 & 2 & 1 & 5 & 1 & 1 & 1 & 4 & 1 & \\
\hline & 1 & 3 & 4 & 1 & 4 & 1 & 1 & 1 & 1 & 1 & 1 & 2 & 2 & 3 & 2 & \\
\hline & 1 & 1 & 2 & 2 & 1 & 1 & 2 & 1 & 2 & 1 & 1 & 1 & 2 & 2 & 1 & \\
\hline & 1 & 1 & 1 & 1 & 2 & 1 & 1 & 1 & 2 & 2 & 1 & 2 & & & & \\
\hline
\end{tabular}

Dari tabel di atas terlihat bahwa aspek perlindungan konsumen secara umum dari sudut pandang konsumen PT. Z berada pada kondisi tidak cukup baik dengan nilai mean 2,43. Hal ini menunjukan bahwa konsumen cenderung tidak setuju terhadap pernyataan perlindungan konsumen telah terjaga dengan baik. Jika dikaitkan dengan kasus yang dianalisis yaitu permasalahan penyalagunaan data konsumen yang berasal dari proses daur ulang kartu SIM bekas, sebagian besar konsumen menyatakan tidak setuju dan sangat tidak setuju terhadap pernyataan bahwa PT. Z memberikan informasi yang jelas dan jujur bilamana terjadi daur ulang terhadap SIM Card yang pernah anda gunakan.

Berdasarkan hasil wawancara dengan beberapa pihak terkait seperti petugas penjaga counter dan beberapa konsumen pengguna diperoleh informasi bahwa permasalahan utama adalah tidak adanya atau belum jelasnya informasi yang diberikan petugas PT. Z kepada konsumen bilamana terjadi daur ulang terhadap SIM Card. Bahkan beberapa konsumen menduga terjadi pemberian informasi yang tidak jujur. Selain itu, keluhan terbesar dari konsumen adalah jika terjadi penyalagunaan data pribadi konsumen oleh pihak lain, terkesan bahwa PT. Z tidak bertanggung jawab dan cenderung lepas tangan. 
Dari hasil survey di atas terlihat bahwa komponen Transparancy dan Responsibility dari prinisp GCG yang menjadi prinisp GCG yang perlu mendapat perhatian utama bagi PT. Z Hasil penelitian ini mendukung hasil penelitian sebelumnya bahwa suatu perusahaan yang dapat menjalankan prinsip GCG secara optimal harusnya akan memberi kondisi perlindungan konsumen yang baik.

\section{Simpulan dan Saran Simpulan}

Dari kajian aspek hukum terlihat bahwa tindakan PT. Z mendaur ulang nomor telepon bekas tanpa adanya informasi tertulis maupun lisan melanggar hak-hak konsumen sebagaimana tercantum dalam Pasal 4 huruf a dan c UUPK serta tidak melakukan kewajibannya sebagai pelaku usaha sebagaimana tercantum dalam Pasal 7 huruf a dan b UUPK. Atas tindakan tersebut pula pihak PT. Z melanggar Pasal 21 UU Telekomunikasi serta melanggar Pasal 26 huruf a dan 27 huruf a dan c Peraturan Menteri Komunikasi 20 Tahun 2016 berkaitan dengan hak pemilik data pribadi serta kewajiban pengguna data pribadi.

Secara keseluruhan proses implementasi prinsip-prinsip GCG di PT. Z dari sudut pandang konsumen belum optimal dengan nilai mean 2,70. Sebagain besar konsumen berpendapat antara tidak setuju dan netral ketika dinyatakan bahwa implementasi prinsip GCG di PT. Z terlah berjalan optimal. Komponen TARIF yang memiliki nilai mean terendah adalah Responsibility (2.06).

Dari aspek perlindungan konsumen secara umum dari sudut pandang konsumen, PT. Z berada pada kondisi tidak cukup baik dengan nilai mean 2,43. Hal ini menunjukan bahwa konsumen cenderung tidak setuju terhadap pernyataan perlindungan konsumen telah terjaga dengan baik.

\section{Saran}

Bagi penerapan GCG ke depan sebaiknya Pihak PT. Z harus beritikad baik dalam menjalankan usahanya dan menyediakan informasi yang benar, lengkap dan jelas berkaitan dengan produk yang diperdagangkannya baik secara lisan maupun tertulis. GCG bertujuan untuk mengatur hubungan-hubungan anara pemangku kepetingan sehingga dapat mencegah terjadinya kesalahan dan untuk memastikan bahwa kesalahan yang terjadi dapat di perbaiki dengan segera

\section{Daftar Pustaka}

Batubara, Hamdan Husein. 2016. "Penggunaan Google Form Sebagai Alat Penilaian Kinerja Dosen di Prodi PGMI Uniska Muhammad Arsyad Al Banjari”. Jurnal Pendidikan Dasar Islam, Vol. 8 No. 1:41.

Budhijanto, Danrivanto. 2014. "Peran Hukum Telekomunikasi Terhadap Implikasi Konvergensi Teknologi Informasi dan Komunikasi”. Jurnal Dinamika Hukum, Vol. 14, No. 1:135.

Kemkominfo. 2018. Analisis Industri Telekomunikasi Indonesia Untuk Mendukung Efisiensi. Puslitbang Sumber Daya, Perangkat, dan Penyelenggaraan Pos dan Informatika. Badan Penelitian dan Pengembangan SDM. 
Khairandy, Ridwan. 2003. Itikad Baik Dalam Kebebasan Berkontrak. Jakarta: Program Pascasarjana, Fakultas Hukum Universitas Indonesia, cet 1:128.

Latumahina R., E. . 2014. "Aspek Hukum Perlindungan Data Pribadi di Dunia Maya”. Jurnal Gema Aktualita, Vol. 3, No. 2:16.

Lianto, Benny; Dachyar, Muhammad; dan Soemardi, Tresna Priyana. 2020. "Modelling the Continuous Innovation Capability Enablers in Indonesia's Manufacturing Industry”. Journal of Modelling in Management:11.

Mansyur, Ali; Rahman, Irsan. 2015. "Penegakan Hukum Perlindungan Konsumen Sebagai Upaya Peningkatan Mutu Produksi Nasional”. Jurnal Pembaharuan Hukum. Volume II No. 1 Januari - April 2015:3.

Marzuki P., M. 2011. Penelitian Hukum. Jakarta: Kencana:93.

Mudashiru, A., A. O.; Bakare, Ibrahim; dan Ishmael, Omah. 2014. "Good Corporate Governance and Organisational Performance: An Empirical Analysis". International Journal of Humanities and Social Science, Vol.4 No. 7:174.

Nugrahaningsih, Widi; Erlinawati, Mira. 2017. "Implementasi Undang-Undang Nomor 8 Tahun 1999 Tentang Perlindungan Konsumen Terhadap Bisnis Online”. Jurnal Serambi Hukum.Vol. 11 No. 01 Februari - Juli 2017:29.

OECD. 2004. The OECD Principles of Corporate Governance:11.

Peni,Emilia.Vähämaa,Sami.2011.”Did Good Corporate Governance Improve BankPerformance during The Financial Crisis”.Journal of Financial Crisis Research:1-30.

Peraturan Menteri Komunikasi dan Informatika Republik Indonesia Nomor 20 Tahun 2016 Tentang Perlindungan Data Pribadi Dalam Sistem Elektronik.

Rajagukguk, Erman. 2000. Pentingnya Hukum Perlindungan Konsumen dalam Era Perdagangan Bebas. Bandung: Mandar Maju:10.

Selvakumar, Marimuthu; Sathyalakshmi, Veluchamy. 2015. "Financial consumer protection and costumer satisfaction. A relationship study by using factor analysis and discriminant analysis". EuroEconomica, Vol. 34 No. 2:71.

Shank, Todd; Hill, Ronald Paul; dan Stang, John. 2013. "Do Investors benefit from good corporate governance". Corporate Governance, Vol. 13 No. 4:1.

Sianipar, Anton Zulkarnain. 2019. "Penggunaan Google Form Sebagai Alat Penilaian Kepuasan Pelayanan Mahasiswa”. Journal of Information System, Applied, Management, Accounting and Research, Vol. 3 No. 1:16. 
Sondakh, Aristide G. S.; Worang, Frederik G.,; dan Pandowo, Merinda. 2017. "Analisa Hubungan Dari Perlindungan Konsumen Terhadap Kepuasan Konsumen di Axa Finance Insurance Manado”. Jurnal EMBA, Vol. 5 No. 3:3534.

Surya, Indra; Yustiavandana, Ivan. 2006. Penerapan Good Corporate Governance (Mengesampingkan Hak Istimewa Demi Kelangsungan Usaha). Penerbit Kencana:25.

Taolin, Maximus L.; Utomo, M. N.; Wahyudi, S.; dan Pangestuti, Irene Rini Demi. 2019. "How does Good Corporate Governance create Customer Trust? The Role of Service Quality and Corporate Image". Journal of Management Systems, Vol. 20, No. 173:39.

Tjizumaue, Magreth Bianca Tareekouje. 2019. "The Relationship between Consumer Awareness, Consumer Protection, Service Quality, Customer Satisfaction and Loyalty among Long-term Insurance Consumers in Namibia”. A dissertation. University of Kwazulu-Natal:184.

Undang-Undang Nomor 8 Tahun 1999 Tentang Perlindungan Konsumen

Undang-Undang Nomor 36 Tahun 1999 Tentang Telekomunikasi

Wawondos, Raymond; Mustamu, Ronny H. 2014. “Analisis Implementasi Prinsip-Prinsip Good Corporate Governance Pada Perusahaan Bidang Cargo di Surabaya”. AGORA, Vol. 2, No. 2:1.

Zhang, Zhe; Lu, Xiaoling; dan Li, Yuzhu (Julia). 2011. "Corporate Governance and Costumer Satisfaction”. International Journal of Business and Social Science, Vol. 2 No. 9:289-292. 